\title{
ע Samanaikaisesti hauras ja resilientti - kategoria-analyysi ikääntyneiden itseä koskevasta puheesta
}

\author{
Marjo Outila \& Pilvikki Lantela
}

Yhteiskuntatieteiden tiedekunta, Lapin yliopisto

\begin{abstract}
Vanhenemiseen liittyvä kulttuurinen kuvasto rakentuu helposti kaksijakoisesti. Janan toisessa päässä ovat aktiiviset, elämästä nauttivat ja yhteiskuntaan panoksensa antavat seniorikansalaiset ja toisessa päässä tarvitsevat ja sairaat vanhukset. Tarkastelemme tässä artikkelissa ikääntyneiden lappilaisten kerrontaa itsestään arkielämän kontekstissa. Tutkimuksen aineisto koostuu 16 ikääntyneen haastatteluista, jotka tehtiin kotiteknologiakokeilun yhteydessä eri puolilla Lappia vuosina 2017-2018. Aineisto on analysoitu kategoria-analyysillä ja tulkinnassa on käytetty resilienssin ja haurauden käsitteitä. Kaikki haastateltavat sijoittivat puheessa itsensä kategorioihin, joiden voidaan katsoa kiinnittyvän haurauteen ja resilienssiin. Voimien väheneminen, kivut ja luopuminen, toisin sanoen hauraus, oli osa ikääntyneiden elämäntodellisuutta. Tämä ei kuitenkaan poissulkenut resilienssiä: ikääntyneiden pystyvyyttä tai asemoitumista oman arkensa aktiivisiksi toimijoiksi. Ikääntyneitä ei tulisi tarkastella yksipuolisesti vain haurauden tai resilienssin näkökulmista, vaikka he ensi silmäyksellä näyttäisivätkin kuuluvan vain toiseen kategoriaan. Molemmat ulottuvuudet tulisi nähdä luontevana osana ikääntymistä ja ikääntymisen kulttuurisia käsikirjoituksia. Ikääntyneillä tulisi olla mahdollisuus toimia ja osallistua mutta samalla mahdollisuus olla täysivaltaisena aikuisena myös tarvitseva, heikko tai hauras.
\end{abstract}

\section{Johdanto}

Länsimaisen vanhuskuvan on sanottu olevan kaksijakoinen (esim. Saarenheimo 2014; 2017). Kulttuuriseen kuvastoomme kuuluvat toisaalta "teräsvaarit tai -mummot", joiden vaativia urheilusuorituksia hämmästelemme arvostaen. Vastakohtana ovat vanhukset, joiden kohtaloa pelkäämme muun muassa mediassa esitettyjen kaltoinkohtelutapausten vuoksi. Näitä vanhuksia kutsutaan yhteiskuntamme taakaksi, koska he tarvitsevat paljon hoivaa ja yhteiskunnan taloudellista panostusta. Nämä kuvat eivät luonnollisesti, vanhuskuvan äärilaitoina, realisoidu suurimman osan ikääntyneiden kokemuksissa omasta elämästään. Niillä on kuitenkin vaiku- 
tusta siihen, millä tavoin ihmiset suhtautuvat vanhenemiseen ja myös ajattelevat itsestään vanhana ihmisenä.

Tarkastelemme tässä artikkelissa, millä tavoin ikääntyneet kertovat itsestään, arjestaan ja elämästään. Analysoimme puheessa tuotettuja vanhuskuvia erityisesti siitä näkökulmasta, millaisiin kategorioihin ikääntyneet asettuvat. Tulkitsemme ikääntyneiden puheessa rakentuvia kategorioita resilienssin ja haurauden käsitteiden näkökulmasta. Vanhuuteen liittyvää kategoriatutkimusta on tehty suhteellisen vähän ikääntyneiden omasta kerronnasta käsin (ks. kuitenkin esimerkiksi Ahosola \& LummeSandt 2016; Róin 2014; Jones 2006; Nikander 2000). Tämän tutkimuksen tarkoitus on täyttää tätä tutkimuksellista vajetta ja arvioida tutkimuksessa esiin nousevien erilaisten kategorioiden ja niiden tuottamien vanhuskuvien merkityksiä.

Haastateltavamme puhuivat vanhuudestaan yhtäältä ihmetellen ikäisekseen hyvää jaksamistaan ja muistamistaan ja toisaalta selittäen vanhuudella oppimisen ja muistamisen ongelmia sekä jaksamattomuuttaan tehdä asioita. Kategoriatutkimuksen näkökulmasta tämän kaltaisessa puheessa on kyse kulttuurisen, ikääntymiseen liittyvän tarinavarannon hyödyntämisestä. Kulttuurissa tarjolla olevien diskurssien, mielikuvien ja tarinoiden avulla rakennetaan kuvaa itsestä tietyn ikäryhmän edustajana. Samalla tavoin rakentuu myös kuva ikääntyneistä tai vanhuudesta yleisesti.

Kysymme tässä tutkimuksessa:

1. Miten ikääntyneet kategorisoivat itseään kertoessaan elämästään haastattelutilanteissa?

2. Miten hauraus ja resilienssi heijastuvat kategorioissa, joihin ikääntyneet sijoittavat itsensä?

\section{Hauraus ja resilienssi tutkimuksen käsitteinä}

Geriatrisessa tutkimuksessa hauraus viittaa yleensä heikentyneeseen fyysiseen tilaan, joka on yhteydessä vanhenemisen haitallisiin seurauksiin ja riskeihin, kuten kaatumiseen ja pitkäaikaiseen sairaalahoitoon (Rockwood ym. 2005; Clegg, Young, Iliffe, Rikkert \& Rockwood 2013). Terveydenhuollon ja sosiaalipalvelujen saralla, diagnostisena tai muuten mitattavana määreenä, hauraus määrittää saatavilla olevia palveluja (Grenier 2006). Toisaalta hauraus (frailty) on myös historiallisesti, sosiaalisesti ja kulttuurisesti rakentuva ja arkipuheessa elävä käsite (Higgs \& Gilleard 2016). Higgsin ja Gilleardin (2015) mukaan länsimaisessa kontekstissa haurauden käsite symboloi epäonnistunutta vanhuutta ja neljättä ikää sekä siihen liittyviä riskejä. Hauraus murtaa mahdollisuuksia toimijuuteen ja horjuttaa yksilön persoonaa ja sosiaalista identiteettiä (Higgs \& Gilleard 2016). Se merkitsee usein myös tarvitsevuutta ja riippuvaisuutta muista, mikä puolestaan yhdistetään autonomian menettämiseen. Hauraus latautuu länsimaisessa kulttuurissa negatiivisesti. Se erottaa "normaalin" ja "onnistuneen" ikääntymisen vanhuudenheikkoudesta (Warmoth ym. 2016; Higgs \& Gilleard 2016). Aiemmissa tutkimuksissa on todettu, että ikääntyneiden kuvaukset heijastavat näitä negatiivisia stereotypioita. Ikääntyneet ovat kuvailleet haurautta heikentyneenä fyysisenä vointina ja toimintakykynä, sairautena sekä tilana, johon liittyy sosiaalisia, psykologisia tai kognitiivisia menetyksiä, epävarmuutta, voimattomuutta, häpeää ja riippuvuutta muista (Puts, Shekary, Widdershoven, Heldens \& Deeg 2009; Grenier 2006; 2007; Warmoth ym. 2016).

Tutkimusten mukaan ikääntyneet eivät halua tulla määritellyiksi hauraiksi vaan vastustavat sitä (Puts ym. 2009; Grenier 2006; Grenier \& Hanley 2007; Warmoth ym. 2016). Grenierin (2006) tutkimuksessa haastateltavat kertoivat haurauden kokemuksista, mutta kieltäytyivät hauraan identiteetistä, johon heidät oli saatettu määritellä palvelujärjestelmässä. Kokemukset hauraudesta liittyivät menetyksiin, epävarmuuteen ja kuolevaisuuteen ja olivat 
näin uhka minän jatkuvuudelle. Warmothin ja muiden (2016) tutkimuksessa vastaajat eivät halunneet identifioida itseään hauraaksi, sillä he ajattelivat sen johtavan terveyttä ja hyvinvointia heikentäviin seurauksiin. Yksi syy haurauden kategorian vastustamiseen voi olla se, että käsite on vastakkainen länsimaisessa kulttuurissa arvostetulle itsenäisyydelle. Itsenäisyyden ja autonomian vastaisesti se merkitsee riippuvuutta muista. (Higgs \& Gilleard 2016; Grenier 2007.) Useimmiten hauraus on määre, jota käytetään silloin, kun muita ihmisiä kategorisoidaan (Grenier 2007; Higgs \& Gilleard 2015).

Haurauteen liittyviä myönteisiä merkityksiä ei ole juuri tarkasteltu tutkimuskirjallisuudessa. Haurauden seurauksena ikääntyneet voivat kuitenkin omaksua uusia tapoja olla yhteydessä itseensä ja maailmaan ympärillään (Nicholson, Meyer, Flatley \& Holman 2013). Se ei estä ikääntyneiden toimijuutta tai kykyä sopeutua menetyksiin ja sairauksien värittämään arkeen (Skilbeck, Arthur \& Seymour 2018).

Haurauden valitseminen tämän tutkimuksen käsitteeksi perustuu haastateltavien puheeseen siitä, kuinka heissä on tapahtunut haastavia muutoksia ikääntymisen tai sairauksien myötä. Haastateltavien haurauteen liittyvä puhe ei kuitenkaan keskittynyt pelkästään omassa itsessä tapahtuneisiin muutoksiin tai ominaisuuksiin vaan myös ympäristöstä ja sen muutoksista johtuviin tai sosiaalisiin suhteisiin liittyviin haasteisiin. Tässä tutkimuksessa haurauden käsitteen avulla analysoidaan haastateltavien puhetta itsestään yksilönä, sosiaalisten verkostojen jäsenenä ja suhteessa ympäristöön.

Hauraus-käsitteen lisäksi tässä artikkelissa aineistoa tulkitaan resilienssin käsitteen kautta. Alun perin psykologiasta tulleella resilienssin käsitteellä viitataan usein yksilön positiivisiin ominaisuuksiin tai kykyihin, joiden avulla hän sopeutuu, selviää tai oppii erilaisista vaikeuksista ja riskeistä tai negatiivisista elämäntapahtumista (Hildon, Montgomery, Blane, Wiggins \& Netuveli 2010; Wild, Wiles \& Allen 2013). Gerontologisessa tutkimuksessa on tarkastel- tu muun muassa sitä, kuinka ikääntyneet selviytyvät terveyteen liittyvistä haasteista, kuten dementiasta tai fyysisestä hauraudesta (Williamson \& Paslawski 2016; Rebagliati ym. 2016) tai läheisen kuolemasta ja surusta (Bonanno, Wortman \& Nesse 2004).

Ikääntyneen resilientiksi tekeviksi ominaisuuksiksi tai kyvyiksi on tutkimuksissa nimetty muun muassa sinnikkyys, itseluottamus, mielekkyyden kokeminen, positiivinen eksistentiaalinen yksinäisyys, mielen tyyneys (Wagnild \& Young 1993), sisäinen "vastustuskyky" (hardiness) joustavuutena sopeutua muutoksiin ja realistisena suhtautumistapana (Fitzpatrick \& Lagory 2003), toivo (Polson, Gillespie \& Myers 2018), tunne mielekkäästä tarkoituksesta, uskomus, että voi vaikuttaa ympäristöönsä, kyky oppia sekä positiivisista että negatiivisista kokemuksista, repressiiviset selviytymisstrategiat sekä positiiviset emootiot (Bonanno 2004). Kvalitatiivisista, ikääntyviä koskevista resilienssitutkimuksista tehdyn metasynteesin mukaan suojaavia tekijöitä ovat: ulkoiset yhteydet, merkityksellisyys, aiempien vastoinkäymisten kokemus, sisukkuus, itsestä huolen pitäminen, itsensä hyväksyminen, positiivinen suhtautuminen elämään, itsenäisyys tai riippumattomuus ja altruismi (Bolton, Praetorius \& SmithOsborne 2016).

Resilienssi on ymmärretty tutkimuksissa yksilöllisten tekijöiden lisäksi yksilö-ympäristösuhteena ja erilaisina prosesseina. Tällöin ikääntyneen resilienssi syntyy esimerkiksi hoivaresurssien ja henkilökohtaisten elämänkokemusten myötä syntyneiden vahvuuksien sekä sisäisten prosessien (esimerkiksi narratiivisuus) tasapainosta (Nakashima \& Canda 2005) tai yksilön ja ympäristön välisestä vuorovaikutuksesta,joka mahdollistaa vaikeuksiin sopeutumisen (Sapountzaki \& Dandoulaki 2006). Myös yhteiskunnallisesti suuntautunut näkökulma painottaa yliyksilöllisten tekijöiden, kuten sosiaalisten erojen ja epätasa-arvoisuuden ja palvelujen, yhteyttä resilienssiresurssien saavutettavuudessa (Marttila, Johansson, Whitehead \& Burström 2013). 
Resilienssi-käsitteen valinta pohjautuu tässä tutkimuksessa ikääntyneiden kerrontaan itsestään elämässään eteen tulleiden vaikeuksien kohtaajina, vaikeuksista selviytyjinä tai niihin sopeutujina. Ikääntyneet rakentavat puheessaan itsessään olevan resilienssin toisaalta omiin yksilöllisiin ominaisuuksiinsa, mutta myös ympäristön, sosiaalisen verkoston ja läheisten ihmisten toiminnan ja olemassaolon ympärille. Tämän vuoksi resilienssiä käsitellään tässä tutkimuksessa yliyksilöllisenä ilmiönä. Hauraus ja resilienssi muodostavat tässä tutkimuksessa käsiteparin, jonka avulla aineistoa on mahdollista analysoida kahdesta näkökulmasta, jotka molemmat olivat merkityksellisiä haastateltavien kerronnassa.

\section{Tutkimuksen aineisto}

Artikkelin tutkimusaineisto koostuu kuudentoista 71-91-vuotiaiden (keskiarvo 85) pohjoissuomalaisen, yksityiskodissaan asuvan ikääntyneen 51 haastattelusta.

Taulukko 1. Haastateltavien perustiedot.

\begin{tabular}{|l|l|l|l|}
\hline Nimi & Ikä & Asuinpaikka & Asuntokunnan koko ja siviilisääty \\
\hline Olavi & 76 & Taajama & Asuu (apua tarvitsevan) puolison kanssa \\
\hline Annikki & 83 & Taajama & Asuu yksin, leski \\
\hline Marjatta & 89 & Kaupunkikeskusta & Asuu yksin, leski \\
\hline Kalevi & 71 & Kaupunkikeskusta & Asuu yksin, leski \\
\hline Liisa & 84 & Taajama & Asuu yksin, leski \\
\hline Kaarina & 85 & Taajama & Asuu yksin, leski \\
\hline Anneli & 86 & Haja-asutusalue & Asuu yksin, leski \\
\hline Maria & 91 & Taajama & Asuu yksin, leski \\
\hline Kyllikki & 84 & Taajama & Asuu yksin, leski \\
\hline Helena & 89 & Haja-asutusalue & Asuu yksin, leski \\
\hline Anja & 85 & Kaupunkikeskusta & Asuu yksin, leski \\
\hline Juhani & 89 & Haja-asutusalue & Asuu yksin \\
\hline Antero & 87 & Haja-asutusalue & Asuu puolison kanssa \\
\hline Eila & 85 & Haja-asutusalue & Asuu puolison kanssa \\
\hline Matti & 88 & Haja-asutusalue & Asuu yksin, leski \\
\hline Anna & 88 & Haja-asutusalue & Asuu pojan kanssa, leski \\
\hline
\end{tabular}

Jokaista ikääntynyttä haastateltiin kahdesta kuuteen kertaan. Haastatteluaineistoa on 1759 minuuttia ja litteroituja sivuja 817 . Haastattelujen lähtökohtana oli tuottaa tietoa iäkkäiden asiakkaiden kokemuksista arjen ja palveluiden sujuvuudesta Toimiva kotihoito Lappiin - Monipuoliset tuen muodot kotona asumiseen (STM) -hankkeen ${ }^{1}$ kehittämistyön tueksi.

1 Ks. http://www.sosiaalikollega.fi/hankkeet/toimiva-kotihoito-lappiin.
Kunnan, esimerkiksi kotihoidon, työntekijät rekrytoivat haastateltavat kehittämishankkeeseen osallistuneiden ikääntyneiden joukosta. Kuntien hankepalavereissa kerrottiin tutkimuksen tavoitteista ja pyydettiin työntekijöitä kysymään hankekokeiluun osallistuvilta lupaa osallistua myös tutkimukseen. Tavoitteena oli saada mukaan monen ikäisiä ja kuntoisia, eri elämänvaiheessa olevia, ja eri puolilla Lappia asuvia miehiä ja naisia. Kuntien työntekijät esittelivät tutkimusta tutkijoilta saadun tiedotteen pohjalta, kysyivät alustavaa suostumusta ja antoivat haastateltaville suostumuslomak- 
keen täytettäväksi. Tämän jälkeen työntekijät ilmoittivat tutkijoille mahdollisen haastateltavan yhteystiedot ja välittivät suostumuslomakkeet. Tämän jälkeen tutkijat soittivat haastateltaville, kertoivat haastatteluista ja niiden tarkoituksesta, varmistivat halukkuuden olla haastateltavana ja tämän jälkeen sopivat haastateltavien kanssa haastattelutavasta (kasvokkain, puhelimitse tai kuvapuhelimen välityksellä). Jokaisen haastattelukerran aluksi varmistettiin halukkuus osallistua jatkohaastatteluihin.

Haastateltavia pyydettiin kuvailemaan muun muassa heidän päiviensä kulkua, palvelujen saatavuutta ja käyttöä, kotona asumisen hyviä puolia ja mahdollisia haasteita sekä kokemuksia kotiteknologioiden käytöstä. Haastateltavan niin toivoessa haastattelutilanteessa oli mukana joku läheinen tai kotihoidon työntekijä. Näin oli kolmen ikääntyneen kohdalla, yhteensä neljässä haastattelussa. ${ }^{2}$

Haastattelut aloitettiin keväällä 2017 ja viimeiset haastattelut tehtiin kesällä 2018. Aineisto on litteroitu sanatarkkuudella ja lisäksi on merkitty, jos puhujat esimerkiksi nauravat sanomisen yhteydessä tai puhuvat kuiskaten. Haastateltavien ja haastatteluissa mainittujen henkilöiden nimet on muutettu. Haastattelukatkelmiin haastateltavat on merkitty seuraavalla tavalla: Marjatta, 89-vuotias, asuu yksin. Tällä tavoin on haluttu tuottaa jonkinlaista kontekstitietoa, vaikka aineiston analyysi ei perustukaan kyseisiin tekijöihin.

\section{Aineiston analyysi}

Aineisto on analysoitu kategoria-analyysillä, joka pohjautuu etnometodologiseen tutkimustraditioon ja edustaa sosiaalis-konstruktivistista tutkimusparadigmaa (Jokinen, Juhila \& Suoninen 2012). Arkielämässä itsen, toisten,

\footnotetext{
2 Haastattelijoina toimivat Lapin yliopistosta artikkelin kirjoittajien lisäksi Satu Peteri ja Kirsi Päykkönen sekä Lapin ammattikorkeakoulusta Greetta Raappana ja Kirsi Valli.
}

eläinten, asioiden ja paikkojen kategorisointi on tapa järjestää, ymmärtää ja tulkita ympäröivää maailmaa. Tutkimuksen näkökulmasta kategorioiden tarkastelu on hedelmällistä, sillä eri kategoriat ovat kulttuurisesti ja moraalisesti latautuneita jäsennyksiä. Eri kategorioihin yhdistetään esimerkiksi "luonnollisia" ominaisuuksia, oikeuksia, velvollisuuksia tai kompetensseja, jotka vaikuttavat siihen, miten kategorian edustajan otaksutaan toimivan, ja mikä on paheksuttavaa tai oletettavaa. (Baker 1997; Sacks 2006; Juhila, Jokinen \& Suoninen 2012; Housley \& Fitzgerald 2009.)

Kategoriat eivät ole universaaleja, vaan ne kiinnittyvät aikaan ja paikkaan sekä yhteiskunnallisiin ja kulttuurisiin diskursseihin. Kategoriat toisaalta ylläpitävät sosiaalista järjestystä ja yhteiskunnallisia rakenteita mutta toisaalta ne myös uudistavat ja muovaavat niitä. Kategorioiden tutkiminen on aina samalla kulttuurin kriittistä tarkastelua. (Juhila ym. 2012.)

Kategoria-analyysia on käytetty laajasti yhteiskuntatieteellisessä tutkimuksessa, esimerkiksi tarkasteltaessa yhteiskunnallisten instituutioiden, luokkien tai ryhmien sekä niihin linkittyvän vallan ja moraalisen järjestyksen rakentumista ihmisten keskinäisessä toiminnassa (Juhila ym. 2012; Butler \& Fitzgerald 2010; Hester \& Eglin 1997; Housley \& Fitzgerald 2009). Ikääntymiseen liittyvässä tutkimuksessa kategoria-analyysia on hyödynnetty suhteellisen vähän (ks. kuitenkin Näslund 2017; Ahosola \& Lumme-Sandt 2016; Pirhonen, Ojala, Lumme-Sandt \& Pietilä 2016; Paoletti \& Gomes 2014; Róin 2014; Nikander 2002; Jolanki 2004; 2009). Pääosin sen avulla on tutkittu ikääntyvien tai ikääntyneiden puhetta itsestään (Nikander 2009; Paoletti \& Gomes 2014; Róin 2014; Ahosola \& LummeSandt 2016; Pirhonen ym. 2016; Jones 2006). Kategoria-analyysia soveltavissa tutkimuksissa toistuvat ikääntymiseen liittyvät negatiiviset kulttuuriset stereotypiat ja mielikuvat. Niissä osoitetaan kuitenkin myös haastateltavan aktiivinen rooli kulttuuristen kategorioiden neuvot- 
telijana, haastajana tai vastustajana (Näslund 2017; Jolanki 2004).

Tämän tutkimuksen analyysi aloitettiin aineistolähtöisesti. Artikkelin kirjoittajat lukivat aineiston läpi ja toivat keskusteluun asioita,joita pitivät aineistossa mielenkiintoisina ja tärkeinä. Eräs näistä asioista oli tapa, jolla ikääntyneet puhuivat itsestään yleisesti ja erityisesti vanhoina ihmisinä. Haastattelukysymyksissä ei ollut kysymyksiä, joilla olisi kysytty suoraan vanhenemisesta. Aineistosta alettiin etsiä puhetta ja tapoja, joilla ikääntyneet kertoivat itsestään. Tällaisia olivat muun muassa omaan terveyteen tai toimintatapojen muutokseen liittyvät puheet. Näitä puheita analysoitiin kategoria-analyysin menetelmin. Oheinen kuvio kuvaa analyysi- ja tulkintaprosessin etenemistä.

\section{Kategoria-analyysin eteneminen}

\begin{tabular}{|c|c|c|c|}
\hline Aineisto & Kategoriat & Yhteiset tekijät & Käsitteet \\
\hline $\begin{array}{l}\text { "kyllä minä ajatuksissani vielä } \\
\text { tajuan kaikki ne asiat, mitä } \\
\text { elämässäni on ollu ja ja myös, } \\
\text { että osaan vielä ajatella ne } \\
\text { asiat, et kaikkee, että mitä } \\
\text { pitää tehä." }\end{array}$ & Pystyvä & \multirow[t]{3}{*}{$\begin{array}{l}\text { - Oman pystyvyyden, } \\
\text { aktiivisuuden ja } \\
\text { pärjäämisen korostaminen } \\
\text { - Omasta arjesta vastuun } \\
\text { ottamisen osoittaminen }\end{array}$} & \multirow[t]{3}{*}{ Resilienssi } \\
\hline $\begin{array}{l}\text { "En mä tarttis semmosta } \\
\text { [ulkoiluttamista]. Kyllä mä } \\
\text { nyt ossaan yksinki käyä tuolla } \\
\text { ulkona." }\end{array}$ & Autonominen & & \\
\hline $\begin{array}{l}\text { "ku on huono olo monestikki } \\
\text { sen huomaa ku joku tullee ja } \\
\text { päläpättää täällä oikeen niin. } \\
\text { Niin tuota sen, silläki mennee } \\
\text { ohi ." }\end{array}$ & Yhteisön jäsen & & \\
\hline $\begin{array}{l}\text { "En minä pärjäis (..) enää, } \\
\text { jos mulla ei olis tuollaset } \\
\text { vakituiset, jotka hoitaa niitä." }\end{array}$ & Autettava & \multirow{4}{*}{$\begin{array}{l}\text { Kertominen } \\
\text { - voimien vähenemisestä } \\
\text { - arjen muutoksista ja voi- } \\
\quad \text { mavarojen vähenemisestä } \\
\text { - avun tarvitsemisesta }\end{array}$} & \multirow[t]{4}{*}{ Hauraus } \\
\hline $\begin{array}{l}\text { "tällä iällä alkaa olla jo vaikea } \\
\text { op...oppia enää uusia asioita." }\end{array}$ & Vanha & & \\
\hline $\begin{array}{l}\text { "[V]aikka olen niin hirviän } \\
\text { paljon järvellä ollu ja kalastanu } \\
\text { yksin ja toisten kans ja sa, } \\
\text { ja savusaunaa lämmittäny. } \\
\text { Mutta ei. Sen jotenki itte } \\
\text { vaistoaa, että se on liian } \\
\text { raskasta." }\end{array}$ & Väsyvä & & \\
\hline $\begin{array}{l}\text { "tämä on ollu aivan mahotonta } \\
\text { tämä minun kipuilu. Koko } \\
\text { talven." }\end{array}$ & Sairastava & & \\
\hline
\end{tabular}

Kuvio 1. Aineiston analyysin ja tulkinnan prosessi. 
Osassa kategorioita korostui ikääntyneen aktiivisuus ja pystyvyys. Haastateltavat puhuivat itsestään pystyvänä, autonomisena ja yhteisön jäsenenä. Toisissa kategorioissa korostui ikääntyneen sairastavuus, heikkovointisuus ja luopuminen. Haastateltavat puhuivat itsestään vanhana, autettavana, väsyvänä ja sairastavana. Näin ollen aineistosta löytyvä kategorisointi oli kaksiuloitteista. Tulkinta kategorioiden kaksiulotteisuudesta oli kiinnostava, koska jokaisen haastateltavan puheesta löytyi molempia kategorioita. Tämän ei pitäisi olla yllättävää, mutta ikääntyneitä koskevat kulttuuriset kuvat ovat usein varsin kaksijakoisia: toisaalta ovat ne ikääntyneet jotka ovat itsenäisiä, aktiivisia ja osallistuvia ja toisaalta ne heikossa asemassa olevat, jotka tarvitsevat paljon tukea ja apua. Haastateltavamme olivat tilanteessa, jossa he tarvitsivat apua, mutta he olivat myös monessa asiassa kykeneviä ja pystyviä. Päätimme tarkastella aineistosta löytyneitä kategorioita haurausja resilienssi-käsitteiden avulla, sillä näissä käsitteissä kiteytyy ikääntyneiden puheessa esiintyvien kategorioiden keskeiset ulottuvuudet ja haastattelupuheiden kaksiulotteisuus.

\section{Tulokset}

Haurauteen liittyvät kategoriat - Sen jotenki itte vaistoaa, että se on liian raskasta nytten

Haastateltavien oman elämän pohdinta nostaa esiin vanhan, autettavan, väsyvän ja sairastavan kategoriat. Tarkastelemme näitä kategorioita haurauden käsitteen näkökulmasta.

Ikääntyneet kertovat haastatteluissa usein voimien vähenemisestä ja arjen muutoksista. He tarkastelevat elämää menneisyyden, nykyisyyden ja tulevaisuuden näkökulmasta. He huomioivat muutoksen suhteessa menneeseen, määrittelevät mitä pystyvät vielä tekemään tai mihin eivät enää kykene ja arvioivat tulevaa. Moni haastateltava toteaa, etteivät voimat enää riitä, tai ettei enää jaksa tai pysty toimi- maan samalla tavalla kuin ennen tai vastaavasti, että vielä jonkin askareen suorittaminen onnistuu. Maria arvioi omaa elämäänsä suhteessa menneeseen.

[V]aikka olen niin hirviän paljon järvellä ollu ja kalastanu yksin ja toisten kans ja sa, ja savusaunaa lämmittäny. Mutta ei. Sen jotenki itte vaistoaa, että se on liian raskasta. (Maria, 91-vuotias, asuu yksin)

Marian ja muiden haastateltavien kertoessa omasta heikentyneestä terveydestään puheen sävy on toteava. Maria ja Anna kertovat heikosta voinnista ja jaksamattomuudesta osana elämän todellisuutta, hyväksyen tai vähintään myöntäen sen. Kategoriaan kuulumiseen yhdistetään tyypillisesti siihen liittyviä oikeuksia tai velvollisuuksia. Helenan mukaan jaksamattomana hänelle kuuluisi oikeus saada apua siivoukseen.

Ja nyt minä oon anonut aluelautakunnalta, että jos kerran kuussa saisin tänne siis, että nuita lattioita vähän pyyhkästäs ja mattoja kopistettas, että en minä niitä ennee jaksa, eikä oo pakkokaan. (Helena, 89-vuotias, asuu $\mathrm{yksin}$ )

Eikä oo pakkokaan ja Helenan puhe siitä, kuinka pittää luopua ja tekkee minkä jaksaa osoittavat kuitenkin, että jaksamattomuutta, haurautta, pitää joissakin tilanteissa selittää (selontekovelvollisuudesta ks. Juhila 2012). Se poikkeaa tavoitteesta, jonka mukaan siivotaan itse ja osallistutaan.

Haastattelija: Tuota, millaiseksi sinä arvioisit oman terveydentilasi, tällä hetkellä?

Eila: No eihän se hyvä ole.

Haastattelija: Mm.

Eila: Mutta kyllä, joo. Se on, et mie en pysty paljon mittään tekemään että. Jos mä vähänkin alan tekkeen jotakin, vaikka ikkunoita pesseen tai muuta, mulle tulee hirveät rintakivut ja. 
Haastattelija: Niin justiinsa

Eila: Semmosta. Ja ruuanlaittokin alkaa käydä nyt semmoseks, että kun mä seison tuossa, niin sitten mä jou'un menemään nukkumaan tuonne.

Haastattelija: Niin justiin, joo

Eila: Tai makkoilemaan, jälkiin ennen kö Maurille laitan ruuan. Ja sitten mie oon, et nyt saat pärjätä yksin, että mä vähän aikaa levähän. Mutta muuten tämä on ihan. Tämmöstä oleskelua ja välillä nukahan (naurahtaa). (Eila, 85-vuotias, asuu puolison kanssa)

Eila vastaa terveydentilaan liittyvään kysymykseen kertomalla, kuinka hän yrittää tehdä kotitöitä, mutta se on hankalaa ja on käynyt yhä hankalammaksi. Eila perustelee pystymättömyyttään hoitaa kodin töitä ja laittaa puolisolleen ruokaa kivuilla ja levon tarpeella. Voimien väheneminen on peruste levätä, jättää kotityöt tekemättä, mutta samalla selonteko vahvistaa käsitystä siitä, että kotitöiden teko kuuluisi asiaan. Toisaalta Eila kertoo varsin neutraalisti siitä, että elämiseen kuuluu paljolti oleskelua.

Vanhan, väsyneen, autettavan tai sairastavan kategorioihin liittyy ikääntyneillä usein muutosta ja sopeutumista. Käytännössä tämä tarkoittaa usein muutoksia toiminnoissa, joiden avulla selviää arjen haasteista. Haastateltavat kertovat, kuinka töitä jaetaan pienempiin osiin tai saadaan apua. Siirtymää haurauden värittämään arkeen kuvaillaan ei enää onnistumisena, ei sitäkään pysty tekemisenä, ei pitkää pätkää jaksamisena ja ei selviämisenä.

Antero: Nämä on nämä omat hommat sitoneet täällä, että tuota, että ku sitä ei pitkää pätkää jaksa kerralla tehä töitä, se pittää jakkaa useampaan.

Haastattelija: Niin justiin, kyllä.

Antero: Useampaan ossaan päivittäin, niin että pysyis kohtalaisen, ettei tarttis ruveta aivan.

Haastattelija: Kyllä, joo.
Antero: Se jos mennee kovin tiukalle, ni sitä ei sitten, sitä ei selviä, kun ne maitohapot kuule [nauraa]. (Antero, 87-vuotias, asuu puolison kanssa)

Haastattelija: Joo, no miten sitten sellaiset siivousasiat? Käykö teillä apua siinä vai? Annikki: No mulla käy tä...tässä vaiheessa mulla on ollut sillai, että se on kerran kuussa käynyt ja nyt mä oon sitä yrittänyt saada, että jos se kävisi kaksi kertaa kuussa, että se siivoaa. Kohta tuntuu, että liikaa sitä pölyä kertyy, kun siinä kuukauden sisään, kun ei mulla itellä enää oikein onnistu se siivoaminen. Tähän saakka se nyt on mennyt, että mä olen siinä välillä sitten ittekin kuitenkin imurilla vetänyt, mutta en mie enää oikein sitäkään pysty tekemään. (Annikki, 83-vuotias, asuu yksin)

Sosiaalisiin ja lähisuhteisiin sijoittuva kategoriasiirtymä, johon haastatteluissa sisältyy haurauden ulottuvuus, on aviopuolisosta leskeksi tai ystävästä ystävän menettäneen kategoriaan siirtyminen.

Haastattelija: Milloinkas teidän puoliso kuoli?

Anna: 2007 marraskuussa.

Haastattelija: No miltä on tuntunut sen jälkeen elämä?

Anna: No kyllä se on se kaipuu aina. Toisinhan aika vaikeatakin $\mathrm{ku}$, varsinkin kun yksinkin on, niin ne hulvalhtelee kaikki mieleen. [nauraa] Kaikki mieleen. Ei se ole yksin, yksin varsin, kyllä mie kolme vuottahan mie olin yksin silloin kun mies kuoli, että, mutta tuo se on pelastanut tuo kuorohomma paljon. En mie ennää pärjäis yksin. Se on niinkö mielenterveydellekin kauhea rasite.

Haastattelija: Niin.

Anna: Että pittää saaha toisten kanssa, toisten kans keskustella ja onneksi täällä, nythän multa kuoli paras kaveri tuosta naapurista. Voi että se on ollu kauhia paik- 
ka. (Anna, 88-vuotias, asuu aikuisen pojan kanssa)

Annan puhe surusta ja kuollutta miestään kohtaan tuntemastaan kaipuusta ja ystävän menettämisen "kauheasta paikasta” kertovat siitä, kuinka hauraus on sidoksissa vuorovaikutukseen ja lähisuhteisiin. Annan mukaan yksin olo johtaisi ei enää pärjäämiseen. Anna asuu aikuisen poikansa kanssa, ja poika tekee suurimman osan kodin töistä. Tätä riippuvuutta Anna ei kuitenkaan esitä ongelmallisena, vaikka muissa haurauteen liittyvissä tutkimuksissa riippuvuus muista on negatiivisesti latautunut asia (Grenier 2007; Higgs \& Gilleard 2016).

Suhde itseen vanhana, autettavana, väsyvänä tai sairastavana on monella tavalla pohdinnan kohteena, mutta nämä kategoriat eivät ole haastateltaville totaalisia kategorioita, jotka märitttelisivät heidät täysin. Olennaista haastateltaville on heikkovointisena tai avun tarvitsijanakin arjen kokeminen mielekkäänä ja tunne minän jatkuvuudesta elämän muuttuessa. Usein minän jatkuvuuteen liittyy ajatus itsestä pystyvänä. Esimerkiksi raha-asioiden hoitamisesta puhuessaan Maria kertoo lasten hoitavan hänen raha-asiansa, mutta lisää, että kaikki kulkee bänen kauttaan.

\footnotetext{
Maria: En minä pärjäis

Haastattelija: Mm.

Maria: Enää, jos mulla ei olis tuollaset vakituiset, jotka hoitaa niitä.

Haastattelija: Nii, et se lasten

Maria: Mut se, et minun kautta kaikki kulkee.

Haastattelija: Niin.

Maria: Ja se on ihan, minä oon aatellu mielekästäki, että niin kauan ku pää toimii, niin siinä on jotain mielekkyyttäki kö on kuitenki asioista perillä.

(Maria, 91-vuotias, asuu yksin)
}

Marian tapauksissa mielekkyyden ja tunteen minän jatkuvuudesta antaa kokemus siitä, että on oman elämän asioista perillä, vaikka käy- tännössä monia asioita ei enää hoidakaan. Seuraavissa haastattelukatkelmissa Anna lähestyy omaa heikentynyttä kykyä tehdä asioita harmituksen, itsensä pakottamisen ja tavoitteeseen yltämättömyyden näkökulmista. Kategoriasiirtymä pystyvästä, töitä tekevästä maatalon emännästä autettavaksi ja hauraaksi on jossain määrin ongelmallinen, sillä se haastaa käsityksen itsestä - Anna on ikäsä tottunu puurtamaan ulkotöissä. Toisaalta Anna osoittaa, että ei ole periksi antavaa tyyppiä, mutta toisaalta toteaa, ettei hän ole pystynyt tekemään mitä haluaisi tai mikä olisi tavoiteltavaa.

Haastattelija: No miten sä arvioisit nytten keväällä sitte että onko menny huonompaan suuntaan, parempaan suuntaan?

Anna: Parempaan suuntaan. Mul on ollu, tämä on ollu aivan mahotonta tämä minun kipuilu. Koko talven. Aivan, on ettei ole... Ei ole kyllä, haluttanu sängystä noussa mutta ko on pakko. Ja se on hyväki kyllä. Haastattelija: Mm.

Anna: Että, vettääpi ylös sängystä. ..

Haastattelija: Niin nyt on ollu noita pihatöitä paljo?

Anna: No pihatöitä ja tuohan se minuu harmittaa ku mie en ole pystyny nuita, etes nuita kukkapenkkiä hoitamaan. Ja sieltä ne vain nousee nuo kukat... [naurua]. $\cdots$

Anna: Ei mulla niin hirveesti harmita mutta, sitäkö on i-ikäsä tottunu että sitä puurtaa tuolla ulukona kesä talvet. Nyt ei mittään.

Anna: Niinkö se sillä lailla, se on elämää maalaistalosa jos tehhään töitä.

(Anna, 88-vuotias, asuu aikuisen pojan kanssa)

Toisaalta haastateltavat myös eksplisiittisesti vastustavat kategorioita, joiden kautta he saattaisivat tulla määritellyksi hauraaksi. On huomionarvoista, että neuvottelut näistä tul- 
kintamme mukaan haurauteen liittyvistä kategorioista tapahtuvat kotona asumisen kontekstissa. Tämä asettaa ikääntyneet monissa tilanteissa asemaan, jossa leimautuminen hauraaksi uhkaa kotona asumista ja jossa on tarve osoittaa kykenevyys kotona asumiseen. Tämä asetelma näkyy Anjan puheessa. Hänen käsityksensä omasta asemoitumisestaan on erilainen kuin palveluntarjoajan. Anja pitää ulkopuolisen tekemää kehnon määritelmää virheellisenä ja asettaa arvioinnin kyseenalaiseksi nimittämällä ulkoilutusta villitykseksi.

Haastattelija: Nii. Ootteko tykänny siitä ulkoiluttamisesta?

Anja: En mä tarttis semmosta. Kyllä mä nyt ossaan yksinki käyä tuolla ulkona.

Haastattelija: Joo..

Anja: Mutta ne aivan kuvittellee että mä oon aivan kehno. Kun kevväällä oli semmonen, että ku mä katoin näin, nii mä menin nurin.

Haastattelija: Joo.

Anja: Nii se on siitä vissiin tämä villitys että on tämmönen ulkoiluttajakin. (Anja, 85-vuotias, asuu yksin)

Haastateltavien reflektoinnissa tulee paikoitellen esille tulevaisuuden epävarmuus ja siihen liittyvät huolet ja pelot. Nämä liittyvät erityisesti kotona asumiseen ja terveyteen. Tällä tavoin hauraus kiinnittyy ajalliseen ulottuvuuteen ja tulee osaksi ikääntyneen itsekategorisoitumista tulevaisuuteen liittyvän pelon tai huolen kautta.

Maria: No, en minä nyt muuta osaa kuin pysyisin semmoisessa kunnossa vaan, että pystyn tässä oleen. Nythän kodinhoitajat käyvät sitten ja eikä tuo muisti menis ja karkais kovin kauas, että osaan tilanteen aina itte arvioida, niin semmoista sitä toivoo. Haastattelija: Mm.

Maria: Että se se olis kaikista tärkeintä. Haastattelija: Kyllä (Maria, 91-vuotias, asuu yksin)
Vaikka haurauteen liittyviin kategorioihin yhdistyy epävarmuutta ja huolta ja vaikka näihin kategorioihin kuulumisesta tai niiden reunaehdoista neuvotellaan, eivät kategoriat ole haastateltavia rampauttavia. Hauraus on osa ikääntyneiden elämäntodellisuutta, johon he ovat sopeutuneet tai johon he päivittäin sopeutuvat. Näin se on kiinteästi yhteydessä resilienssiin (Fitzpatrick \& Lagory 2003). Kategoriat eivät ole haastateltavien puheessa joko-tai vaan sekä-että, haurauspuhe rakentuu yhteydessä resilienssipuheeseen.

\section{Resilienssiin liittyvät kategoriat - Mie} aina, mie yritän jotakin tebä.... Sikäli ku pystyn.

Kategorioita, joissa korostuvat omasta arjesta vastuun ottaminen, pystyvyys, aktiivisuus ja pärjääminen, ovat pystyvän, autonomisen ja yhteisön jäsenen kategoriat. Näitä aineistossa löytyviä kategorioita tarkastelemme resilienssikäsitteen avulla. Kategorioiden yhteydessä haastateltavat asemoituvat aktiivisen toimijan rooliin, jossa he ovat vastuussa oman arkielämänsä toimista ja määrittelevät elämänsä kulkua. Nämä kategoriat rakentuvat esimerkiksi haastateltavien kertoessa arkipäiviensä kulusta: aamuaskareistaan, kodista huolen pitämisestä ja asioiden hoidosta.

Haastattelija: No sellaista vielä voisin kysyä, että millainen on sellainen tyypillinen päivä teille? Tyypillinen arkipäivä, että mitäs tapahtuu?

Anna: [...] mie aina, mie yritän jotakin tehä. Haastattelija: Hmm.

Anna: Sikäli kö pystyn. Siivota vessan tai käyä pyykinpesusa tuolla, eihän sitä muuta tartte ku laittaa konheeseen ja ottaa pois, niin se tuo pannee kuivhaan ku mul on niin huonot käjet. Ja tuota, mitä mie nyt paljo tekisin? Kyllä mie tietenkin, jos näinkin mennee, niin saatan vähän siivotakin ja pyyhkiä lattioita ja, mie aina keksin jotakin. 
Ko sekin, se on hankala ko ei pysty käsitöitä tekkeen. Se se ois hyvää ajankulua.

(Anna, 88-vuotias, asuu aikuisen pojan kanssa)

Vaikka haastateltavien arkielämän valinnan mahdollisuudet ovat monella tavalla rajallisempia aiempaan elämään nähden, löytävät haastatellut kuitenkin keinoja kuvata itsensä aktiivisena ja itsenäisenä toimijana. Arkipäivästään kertoessaan Anna asemoi itsensä aktiiviseksi toimijaksi, vaikka muuten hän haastattelussa viittaa usein heikkoon ja vaihtelevaan terveydentilaansa. Vaikka Anna viittaa myös tässä katkelmassa eksplisiittisesti terveydentilaansa liittyviin haasteisiin mulla on niin buonot käjet tai ko ei pysty käsitöitä tekkeen, hän kuitenkin korostaa omaa rooliaan pystyvänä toimijana. Mie aina, mie yritän viittaa aktiivisuuteen ja moraaliseen velvollisuuteen tehdä oma osansa mahdollisista ongelmista huolimatta. Sana aina vahvistaa Annan argumentointia. Anna tekee myös myönteisen tulkinnan terveydentilansa suunnasta - vaikka hän ei ole moneen kuukauteen siivonnut kotona, hän arvelee, että saattaa vähän siivoillakin jos näinki mennee, eli jos terveydentila kohenee.

Ilmari on tehnyt koko työuransa fyysistä työtä, mutta terveysongelmien vuoksi hän on joutunut luopumaan monesta tekemisestä. Nykyään Ilmari liikkuu vain harvoin kodin ulkopuolella ja kotipihalla kävelykin on haastavaa. Arkipäivästään kertoessa Ilmari valitsee kerrontaan juuri sen asian, josta hän pystyy vielä omatoimisesti suoriutumaan.

Haastattelija: Jos vielä semmosta kyselisin, että minkäslainen teillä on semmonen tyypillinen päivä? Jos kertositte semmosesta? Ilmari: No se on, tota [...] sähköllä ja puilla tämä lämmitys, ni minä sähköä säästäessä, ni mulla on halakoja vaikka kuinka paljon ne pojat ruukaa mulle siirtää tuohon pannuhuoneeseen ja liiteriin. Minä siitä, sitte vielä kerran päivässä käyn, käytän tulia nyt varsinki nyt ku kylmempi ilima on, ni piän takassa tulta. Takassa pannuhuoneessa tulta. (Ilmari, 88-vuotias, asuu yksin)

Ilmarin puhetapa korostaa hänen pärjäämistään ja sopeutumistaan elämän muuttuneisiin olosuhteisiin. Omaa pystyvyyttä, käsitteellisesti resilienssiä, tuotetaan myös korostamalla omia kognitiivisia kykyjä; vaikka Maria on joutunut luopumaan monien arkiaskareiden hoitamisesta, hän korostaa kykyään edelleen ajatella ja ymmärtää.

Haastattelija: Niin, mutta vielä ootte pystyny tässä kotona asuu?

Maria: Kyllä ja kyllä minä, kyllä minä asiat ymmärrän, mutta se on menny semmoseks hitahaks, että ei pysty ilimasehe niitä niin, niin sillä lailla luontevasti, ilman muuta.

Haastattelija: Aivan.

Maria: Mutta tuota kyllä minä ajatuksissani vielä tajuan kaikki ne asiat, mitä elämässäni on ollu ja ja myös, että osaan vielä ajatella ne asiat, et kaikkee, että mitä pitää tehä. Haastattelija: Mm.

Maria: Sittehän se menee toivottomaks olla yksin, jos ei sitä, jos ne pian putoaa. (Maria, 91-vuotias, asuu yksin)

Tässä katkelmassa haastattelija huomaamattaan asemoi Marian selontekovelvolliseksi. Marian vastaus muotoutuu korkean iän ja kotona asumisen kontekstissa. Viittaamalla kykyyn ymmärtää ja ajatella asiat Maria osoittaa haastattelijalle pystyvänsä edelleen asumaan kotona. Marian vastaus heijastaa myös kulttuurista stereotypiaa ikääntymisestä höperöitymisenä. Tarve selvittää omaa kykyään ajatella viittaa siihen, että se on yli 90-vuotiaalle poikkeuksellinen ominaisuus. Toisto on keino vahvistaa viesti kuulijalle. Aineistokatkelma kuvaa myös hyvin kategorioista neuvottelua, johon viitattiin aiemmin. Myöntämällä iän myötä tulleen hitauden ja itsensä ilmaisemisen vaikeutumisen Maria asemoituu jossain määrin 
ongelmalliseen vanhan kategoriaan, mutta kuitenkin hän painottaa heti perään omaa pystyvyyttään kertomalla, että ongelmista huolimatta kyky "ajatella asiat" on tallella.

Myös muissa haastatteluissa keskustelu kotona asumisesta nostaa esiin oman pystyvyyden osoittamisen. Osa haastateltavista on käynyt keskusteluja kotoa pois muuttamisesta kotihoidon työntekijöiden, lasten tai muiden läheisten kanssa. Kukaan haastateltavista ei kuitenkaan arvioi itseään kotona asumiseen pystymättömäksi vaan pikemminkin he perustelevat kotona pärjäämistään.

Haastattelija: Joo, no jos miettii sitä omassa kodissa asumista, niin, niin mitä hyviä tai huonoja puolia siitä tulisi mieleen?

Olavi: No tämähän on erittäin hyvä tämä, että saamme kumpikin Kaarinan kanssa olla täällä kotona. Ja emmie ainakaan lähde vielä muualle, niin emme me siinä kunnossa ole, että meidän tarttis lähteä vielä muualle.

Haastattelija: Joo. Ei oo vielä ollut puhetta, että tarvisi mihinkään

Olavi: On puhetta ollut, mutta tuota, kyllä me, kyllä me pärjäämme vielä tässä ihan kotioloissa.

(Olavi, 76-vuotias, asuu apua tarvitsevan puolison kanssa)

Pystyvyyspuheessa korostuu myös kyky ja taito sekä moraalinen velvollisuus huolehtia itsestään, esimerkiksi terveydestään.

Haastattelija: Mitä tuo kotihoito täällä tekee? Auttaaks se niihen lääkkeiden annostelus vai mitä he käy?

Maria: Ei mul oo tarvinnu. Kyllä ne varmasti tekee sitäki, jos tarttee, mutta minä olen aika tarkka näissä hommissa, että.

Marian poika: Se on sillai, että mummu jakaa vielä itse, mutta ne maanantaina niin tarkistavat [päällekkäistä puhetta].

Maria: Niillä oli määräys tullu, että niiden pitää maanantaina käydä tarkistamassa se, kun minä jaan sen viikon annoksen ja, mutta minä olen niin kauan tehny sitä ja sillai kyllä minä periaatteessa olen semmosissa asioissa niin tarkka, että en tohlaile. Että, ja jotenki tykkäänki siitä, että minä saan itte tehä. Se vähä kohentaa sitä itsetuntoa.

(Maria, 91-vuotias, asuu yksin)

Minun on hyvä kävellä. Minulta mennee jaloista voima, jos en minä, minä vain makkuu, makkaan ja istuksin. Että täytyy pittää huoli tuosta omasta terveyestä, niin viime viikolla kävi tämä naapuri tuomassa postin, kun olin, olin sillon huonossa kunnossa, mutta seuraavana päivänä minä menin ite hakemaan ja tänäki päivänä. Minulla on sauvat, jotka, joittenka turvin minä kävelen, että en kaavu siellä ja on minulle hommattu on tämä ranneke, että voin sillä hälyttää, kun, jos kaatuu tuonne, niin ei taho päästä ylös. (Helena, 89-vuotias, asuu yksin)

Maria korostaa omaa osaamistaan ja kykyään huolehtia lääkkeenotosta, sijoittaen tällä tavalla itsensä pystyvän kategoriaan. Helenan puheessa terveydestä huolehtiminen on moraalinen velvollisuus, siitä "täytyy" pitää huolta. Helena myös osoittaa elävänsä tämän moraalisen velvoitteen mukaisesti. Huonovointisuus vaikeuttaa omaa aktiivisuutta, mutta aina kun mahdollista, hän esimerkiksi, mahdollisista riskeistä huolimatta, hakee itse postin.

Haastateltavat korostavat kerronnassaan myös muihin kiinnittymisen ja sosiaalisen vuorovaikutuksen merkitystä. Resilienssiin liittyviin kategorioihin kiinnittyvä kerronta pitää usein sisällään puhetta toisista ihmisistä, joko konkreettisen avun antajina, henkisen hyvinvoinnin ja pärjäämisen tukijoina sekä turvallisuuden lähteenä.

Haastattelija: Joo mutta että terveys on ollu parempaan päin?

Anna: No kyllä niin voi sanoa kyllä. Kyllähän niitä tullee aamullaki oli niin paha olo että, että pitikö minun soittaa että älä- 
kää hyvät ihimiset tuluko ei minusta [naurahdus] nyt mihinkään oo että, niin se siitä taas. Söi ja, joi vettä ja, kuunteli ja katteli niin siitä se taas.

Haastattelija: Mm. Onko se paha olo fyysistä vai onko myös sitte että mieli on maassa? Anna: [ähkäisy] No se on varmaan sitäki. Että mieli on maasa.

Haastattelija: Mm.

Anna: Ja tuoki etova tunne on, en tiiä kumpaa se, kumpaan kategoriaan se [naurahdus] laskis. Mutta tuota.. Kyllä se, ku on huono olo monestikki sen huomaa ku joku tullee ja päläpättää täällä oikeen niin.. Niin tuota sen, silläki mennee ohi.

Haastattelija: Mm.

Anna: Että kyllä mie olen sanonu että miusta ei yksinolijaksi olis yhtään.

(Anna, 88-vuotias, asuu aikuisen pojan kanssa)

Kerronta itsestä yhteisön jäsenenä tai vuorovaikutussuhteen osapuolena kiinnittää ikääntyneen moninaisiin sosiaalisiin verkostoihin. Anna kertoo kuinka muiden seura parantaa oloa, eikä hän usko pärjäävänsä yksin. Pärjäävä, pystyvä itse rakentuu Annan puheessa ihmissuhteissa. Toisesta näkökulmasta katsottuna pärjäävää itseä on vaikea kuvitella olevan olemassa ilman muiden ihmisten läsnäoloa. Hauraus ja resilienssi kiinnittyvät siis sosiaaliseen ja ihmissuhdeverkostoihin. Niillä saattaakin olla erittäin merkittävä rooli ikääntyneille esimerkiksi minän jatkuvuuden näkökulmasta.

\section{Johtopäätökset}

Haurauteen viitataan tutkimuskirjallisuudessa monella tapaa ongelmallisena ilmiönä. Sitä pidetään epäonnistuneen tai epäonnisen vanhenemisen tekijänä: riskinä (ks. esim. Rockwood ym. 2005; Clegg ym. 2013) tai merkitykseltään negatiivisena tekijänä (Higgs \& Gilleard 2015; 2016; Warmoth ym. 2016; Puts ym.
2009; Grenier 2006; 2007), jota vastustetaan esimerkiksi itseidentifikaation tai -kategorisoinnin lähteenä (Puts ym. 2009; Grenier 2006; Grenier \& Hanley 2007; Warmoth ym. 2016; Higgs \& Gilleard 2015; 2016; Grenier 2007).

Aineistossamme ilmentyvä haurauden vastustaminen tai siihen liittyvien kategorioihin kuulumiseen liittyvä selontekovelvollisuus voidaan tulkita vallitsevan tutkimusnäkemyksen mukaisesti haurauden ekskluusiona. Jos ilmiötä tarkastelee niiden tutkimustulosten valossa, joissa on osoitettu taipumus yhdistää hauraus vanhan iän negatiivisiin stereotypioihin (Bai 2014; Featherstone \& Hepworth 2005), kyse on myös ageismista tai vanhuuden sosiaalisesta ekskluusiosta. Ageismin seurauksena on pidetty vaikeutta mieltää itseä vanhaksi (Featherstone \& Hepworth 2005; Nikander 2000), etäisyyden ottoa vanhan kategoriaan, tai kategorian vastustamista (Näslund 2017; Róin 2014).

Toisaalta kategorisointiin liittyvä haurauspuhe saattaa myös muotoutua diskursiiviseksi välineeksi, jota ikääntyneet käyttävät tarpeen vaatiessa omaksi edukseen ja joka mahdollistaa osallisuuden niukentuviin resursseihin ja palveluihin (Grenier 2007; Grenier \& Hanley 2007). Haastatteluissamme haurauteen liittyviin kategorioihin (sairastava, väsyvä, autettava, vanha) kuuluminen nähtiin yhtäältä perusteluina palvelujen saantiin. Toisaalta näihin kategorioihin kuulumista varottiin, koska niiden katsottiin estävän pystyvän ja omassa kodissa pärjäävän, aikuisen ihmisen kategoriaan kuulumisen ja olevan täten riski kotona asumisen jatkumisen suhteen. Ikääntyneen sijoittaminen hauraaksi saattaa mahdollistaa hoivan, mutta toisaalta se saattaa myös rajata ikääntyneen toimintavapautta ja autonomiaa (Higgs \& Gilleard 2016; Grenier 2007).

Vaikka haurauteen liittyy menetyksiä ja luopumista, se voidaan nähdä uudenlaisina tapoina olla yhteydessä itseensä ja toisiin. Hauraus voi merkitä uudenlaisen toimijuuden ja sopeutumiskyvyn löytymistä. (Nicholson ym. 2013.) 
Haastateltavamme eivät varsinaisesti tarkastelleet haurauttaan positiivisessa valossa, mutta toisaalta he eivät myöskään jääneet kiinni haurastumisen mukanaan tuomiin uhkiin; aineistosta välittyy realistinen suhtautumistapa ikään liittyvään haurastumiseen. Toisaalta ikääntyneet reflektoivat mahdollista tulevaa haurautta ja sen tuomia muutoksia terveyteen, pärjäämiseen ja kotona asumisen mahdollisuuteen.

Haastateltavamme puhuivat paljon itsestään pärjäävinä ja keinoista, joiden avulla asiat tulevat hoidetuiksi haasteista huolimatta. Resilienssitutkimuksen käsitteistä ja tuloksista tulivat puhutuiksi erityisesti sinnikkyys (Wagnild \& Young 1993; Bolton, Praetorius \& Smith-Osborne 2016), joustavuus ja realistisuus (Fitzpatrick \& Lagory 2003), yhteydet muihin ihmisiin ja asioihin, itsestä huolen pitäminen ja itsensä hyväksyminen sekä itsenäisyys (Bolton, Praetorius \& Smith-Osborne 2016), hoivaresurssien ja henkilökohtaisten elämänkokemusten myötä syntyneet vahvuudet (Nakashima \& Canda 2005), yksilön ja ympäristön välinen joustavuus (Sapountzaki \& Dandoulaki 2006) ja palvelujen saanti (Marttila, Johansson, Whitehead \& Burström 2013).

Ikääntyneiden puheessa esiintyneet resilienssiin liittyvät kategoriat voidaan tulkita pyrkimyksenä rakentaa sosiaalista identiteettiä ja arvoa (ks. Jolanki 2004) tai vanhuuteen liittyvien negatiivisten diskurssien vastapuheena, itsetodisteluna (ks. Suoninen 2012), joka on hienovarainen tapa vastustaa haurautta ja korostaa omaa pärjäävyyttä. Mielestämme näiden kategorioiden voidaan yhdessä katsoa rakentavan aikuisen kategoriaa, johon ikääntyneet sijoittavat itsensä. Aineistostamme löytyy kohtia, joissa ikääntyneet korostavat aikuisuuteen kulttuurisesti yhdistettyjä taitoja: yleistä elämänhallintaa ja itsestä huolehtimista. Jos arkiaskareiden hoitaminen on muuttunut vaikeaksi, aikuisen kategoriaa rakennetaan osoittamalla, että kyky ajatella ja ymmärtää asioita on fyysisestä heikkokuntoisuudesta huolimatta edel- leen tallella. Tällä tavoin rakentuu peruste saada aikuisuuteen kulttuurisesti linkitettyjä oikeuksia: oikeuden päättää oman elämän asioista ja elää valitsemansa elämäntyylin mukaan.

Itsetodistelu on tulkintamme mukaan yhteydessä terveen, onnistuneen tai aktiivisen vanhenemisen ideaaliin, johon on yhdistynyt yksilöllisen vastuun suuri rooli läntisissä kulttuureissa (Jones \& Higgs 2010). Velvoite pitää itsestä huolta tulee esiin myös Róinin (2013) tutkimuksessa,jossa färsaarelaisten eläkeläisten puheessa itsestä huolen pitäminen, esimerkiksi liikunta, on velvollisuus, joka on sidoksissa hyvin ja oikein ikääntyvien kategoriaan. Myös Ahosolan ja Lumme-Sandtin (2016) tutkimuksessa omaisettomat vanhat ihmiset tuottivat puheessaan vanhuspolitiikan toivekuvaa aktiivisesta, itsenäisestä ja vastuullisesta vanhuudesta. Vaikka negatiiviseksi koettu haurausdiskurssi on saanut rinnalleen ensi silmäyksellä positiivisia ikääntyneiden kategorioita (aktiivinen, terve, kolmatta ikää elävä), aktiivisen tai onnistuneen ikääntymisen vaateet voivat mennä niin pitkälle, että ihmiset, jotka eivät syystä tai toisesta yllä ideaalin, joutuvat kärsimään sen seurauksista (São José, Timonen, Amado \& Santos 2017; Lamb 2014).

Yksi tapa osoittaa resilienssiä on vedota muihin ihmisiin oman resilienssin todistajina. Haastateltavamme kertoivat, kuinka kotihoidon työntekijä, lääkäri, naapuri tai tuttavat tietävät tai ihmettelevät heidän pärjäämistään (ks. myös Jolanki 2004). Tällaisella puheella voidaan myös pyrkiä erottautumaan oletetusta, normatiivisesti latautuneesta hauraudesta (ks. esim. Coupland, Coupland \& Giles 1989). Pirhosen ja muiden (2016) mukaan itsensä etäännyttämistä vanhan kategoriasta tehdään esimerkiksi tulkitsemalla omia kykyjä uudelleen tilanteessa, jossa joissain kyvyissä on tapahtunut muutoksia. Yksi keino on vertailu heikompikuntoisiin (Pirhonen ym. 2016).

Joskus haastateltavat puhuivat itsestään kykenevänä asioihin, joihin he eivät haastattelijan arvion mukaan käytännön tasolla kyenneet. 
Tulkintamme mukaan myös tämä on seurausta resilienssin osoittamisen kulttuurisesta vaateesta tai uudenlaiseen minään totuttautumisen keskeneräisyydestä. Kykenevyyspuhe linkittyy myös vahvasti kotona asumiseen - puhe on ikääntyneiden toimintaa mahdollista kotoa pois muuttamisen uhkaa vastaan.

Tulkitsimme ikääntyneiden puheessa olevia itseä kuvaavia kategorioita resilienssin ja haurauden näkökulmista. Tutkimuksemme yksi keskeisimmistä tuloksista on se, että haastateltavamme kategorisoivat itseään sekä resilienssiin että haurauteen liittyviin kategorioihin. Ikääntyneiden puheessa ei rakennu samanlainen kahtiajakoisuus, mikä on nähtävissä populaarissa tai poliittisessa puheessa. Itsestään puhuessaan ikääntyneet sijoittavat itsensä kategorioihin, jotka liittyvät resilienssiin ja haurauteen, ei vain toiseen niistä. Kun ikääntyneet kertoivat elämäänsä ja itseensä liittyvistä haasteista ja hauraudesta, he liittivät puheeseen resilienssiin kiinnittyviä teemoja, esimerkiksi kertomuksia keinoista, joilla he olivat selvinneet vaikeista asioista. Kyse oli joko konkreettisista käytännön keinoista, epävirallisista ja virallisista verkostoista ja avun saannin tavoista tai uusiin elämäntilanteisiin liittyvistä suhtautumiskeinoista tai sopeutumistavoista.

Ikääntyneet käyttivät haurauteen ja resilienssiin liittyviin kategorioihin itsensä sijoittamista diskursiivisena välineenä välittääkseen itsestään tietynlaisen kuvan ja toisaalta välttääkseen ei-toivottuja vaikutelmia. Näin itsekategorisointi toimi sosiaalisen identiteetin rakentamisen välineenä. Itsekategorisointiin liittyy myös moraalinen ulottuvuus. Haurauteen liittyviin kategorioihin liitettiin muun muassa oikeus apuun ja tukeen ja resilienssiin liittyviin kategorioihin velvollisuus pitää huolta toimintakyvystä ja terveydestä sekä oikeus kotona asumiseen haasteista ja tuen tarpeista huolimatta. Kategorisointi oli myös keino reflektoida omaa elämää ja itseä. Esimerkiksi silloin, kun terveydentila vaihteli huomattavasti tai tukea antavien läheisten elämäntilanteissa tai palveluissa tapahtui merkittäviä muutoksia, myös kategoriat, joihin haastateltavat asettuivat, muuttuivat. Uudenlainen kategorisoituminen, monenlaisten kategorioiden rinnakkaisuus, nopeat kategoriasiirtymät tai tuttuun kategoriaan kuulumisesta luopuminen herättivät pohdintaa omasta elämästä ja itsestä. Esiin nousseet kysymykset koskivat sitä, millainen minä olen ja millainen tulevaisuus minulla on.

\section{Pohdinta}

Ikäkategorioihin liittyvillä kulttuurisilla käsikirjoituksilla on voimakas vaikutus siihen, mitä ihmisiltä odotetaan ja mitä heiltä evätään (Näslund 2017; Zimmerman \& Grebe 2014). Ikääntyneiden, kuten kaikkien muidenkin ikäryhmien, elämässä on asioita, joita voidaan kuvata haurauden ja resilienssin käsitteillä. Tutkimuksemme ikääntyneilläkin on elämässään monia haurautta tuovia tekijöitä, kuten sairauksia ja menetyksiä, mutta myös resilienssiä synnyttäviä asioita, esimerkiksi sinnikkyyttä, elämänkokemusta, ihmissuhteita ja palveluja. Ajatus siitä, että haastateltaviamme, tai ikääntyneitä ylipäänsä, tarkasteltaisiin yksipuolisesti joko resilienssin tai haurauden näkökulmasta, on huolestuttava. Jos ikääntyneiltä vaaditaan resilienssiä yli voimavarojen, heidän haurautensa ja mahdollinen tuen tarpeensa voi jäädä näkemättä tai se voidaan ohittaa (Wild, Wiles \& Allen 2013). Toisaalta pelkästään hauraan kategoriaan sijoitetulta voidaan evätä mahdollisuus toimia, osallistua ja tehdä valintoja oman elämänsä suhteen.

Tutkimuksemme mukaan on tärkeää kiinnittää huomiota ikääntyneiden kategorisointiin. Kategoria-analyysin avulla on mahdollisuus tunnistaa ikääntymiseen ja ikääntyneisiin liitettyjä moraalisia järjestyksiä sekä eri kategorioihin kiinnittyviä oikeuksia ja velvollisuuksia. Vanhuspalveluissa tulisi huomioida seuraavat ikääntyneiden itseä koskevan kategorisoinnin piirteet, jotka liittyvät muun muassa ikäänty- 
neiden asiakkaiden asemaan ja palvelutarpeeseen vastaamiseen sekä kokemukseen palvelun laadusta:

Haurauteen liittyvä itsen kategorisointi voi olla yhteydessä ikääntyneen tyydyttymättömään avun ja tuen tarpeeseen sekä kokemukseen oikeudesta avunsaantiin. Esimerkiksi sairaaksi, väsyväksi tai autettavaksi itsensä määrittelevä ikääntynyt voi ajatella, että hänellä on oikeus yhteiskunnan tai läheisten taholta tarjottavaan apuun, mutta hän ei saa tarvitsemaansa tukea. Tällainen avun tarve tulisi tunnistaa.

Ikääntyvän puhetta, joka sisältää selontekovelvollisuutta, tulee kuunnella tarkasti, jottei piiloon jäävä hauraus ja palvelutarve jää tunnistamatta. Ikääntyneet saattavat omassa elämänkontekstissaan asemoitua selontekovelvollisen asemaan, jolloin pärjääminen ja pystyvyys ylikorostuvat, eikä tuen tarvetta välttämättä tunnisteta.

Erilaiset kategorisoimiskäytännöt tulisi tunnistaa. Esimerkiksi ikääntyneellä ja kotihoidon työntekijällä voi olla erilainen näkemys kategoriasta, johon ikääntynyt kuuluu. Ikääntynyt voidaan nähdä liian kykenevänä ja hän jää ilman tarvitsemiaan palveluja, vaikka palvelun saannin kriteerit

\section{Lähteet}

Ahosola, P. \& Lumme-Sandt, K. (2016). “Sen haluan ilmoittaa, että minä olen vielä pystyssä”: Ilman omaisia elävien vanhojen ihmisten toimijuus ja vanhuspolitiikan kategorisoima vanhuus. Gerontologia, 30(4), 182-197.

Bai, X. (2014). Images of ageing in society: a literature review. Journal of Population Ageing, 7(3), 231-253. doi:10.1007/s12062-014-9103-x

Baker, C. (1997). Membership categorization and interview accounts. Teoksessa Silverman, David (toim.) Qualitative research. Theory, method and practice (s. 130-143). London: Sage.

Bolton, K., Praetorius, R. \& Smith-Osborne, A. (2016). Resilience protective factors in an older täyttyisivätkin. Toisaalta ikääntynyt voidaan nähdä kykenemättömämpänä kuin hän onkaan, jolloin myönnetyt palvelut saattavat kohdentua väärin.

Ikääntyneet voivat tarvita apua kategoriasiirtymiin liittyvien asioiden ja tunteiden käsittelyssä. Esimerkiksi siirtymä autonomisesta autettavaksi tai pystyvästä väsyväksi voi olla muutos, jossa ikääntynyt tarvitsee psykososiaalista tukea.

Ikääntyneiden puheeseen sisältyvä kategorisointi sisältää usein itseen kohdistuvaa reflektointia. Tätä voisi hyödyntää palveluissa työntekijän ja asiakkaan vuorovaikutuksen resurssina silloin, kun halutaan selvittää asiakkaan tulkintoja omasta tilanteestaan (esimerkiksi kotona asumiseen liittyvistä voimavaroista ja ongelmista) ja palveluja kohtaan asetetuista toiveista ja odotuksista.

\section{Yhteydenotto:}

Marjo Outila, YTM, yliopisto-opettaja, Lapin yliopisto, Yhteiskuntatieteiden tiedekunta, sähköposti: marjo.outila@ulapland.fi

Pilvikki Lantela, HM, väitöskirjatutkija, Lapin yliopisto, Yhteiskuntatieteiden tiedekunta, sähköposti: pilvikki.lantela@ulapland.fi

adult population: a qualitative interpretive meta-synthesis. Social Work Research, 40(1), 171-182. doi:10.1093/swr/svw008

Bonanno, G. (2004). Loss, trauma, and human resilience: have we underestimated the human capacity to thrive after extremely aversive events? American Psychologist, 59(1), 20-28.

Bonanno G., Wortman C. \& Nesse R. (2004). Prospective patterns of resilience and maladjustment during widowhood. Psychology and Aging, 19(4), 260-271. doi:10.1037/0882-7974.19.2.260

Butler, C. \& Fitzgerald, R. (2010). Membership-in-action: operative identities in a family meal. Journal of Pragmatics, 42(9), 2462-2474. 
Clegg, A., Young, J., Iliffe, S., Rikkert, M. \& Rockwood, K. (2013). Frailty in elderly people. The Lancet, 381(9868), 752-762. doi:10.1016/S0140-6736(12)62167-9

Coupland J., Coupland N. \& Giles H. (1989). Telling age in later life: identity and face implications. Text, 9(2), 129-151. doi:10.1515/text.1.1989.9.2.129

Featherstone, M. \& Hepworth, M. (toim.) (2005). Images of ageing: cultural representation of later life. London: Routledge.

Fitzpatrick, K. \& Lagory, M. (2003). "Placing” health in an urban sociology: cities as mosaics of risk and protection. City $\mathcal{E}$ Community, 2(1), 33-46. doi:10.1111/1540-6040.00037

Grenier, A. (2006). The distinction between being and feeling frail: exploring emotional experiences in health and social care. Journal of Social Work Practice, 20(3), 299-313. doi:10.1080/02650530600931849

Grenier, A. (2007). Constructions of frailty in the English language, care practice and the lived experience. Ageing E Society, 27(3), 425-445. doi:10.1017/S0144686X06005782

Grenier, A. \& Hanley, J. (2007). Older women and 'frailty': aged, gendered and embodied resistance. Current Sociology, 55(2), 211-228. doi:10.1177/0011392107073303

Hester, S. \& Eglin, P. (toim.) (1997). Culture in action. Studies in membership categorization analysis. (No. 4). University Press of America.

Higgs, P. \& Gilleard, C. (2015). Rethinking old age: theorising the fourth age. London: Macmillan International Higher Education.

Higgs, P. \& Gilleard, C. (2016). Personhood, identity and care in advanced old age. Bristol: Policy Press.

Hildon Z., Montgomery S., Blane D., Wiggins R. \& Netuveli G. (2010). Examining resilience of quality of life in the face of health-related and psychological adversity at older ages: what is "right" about the way we age? Gerontologist, 50(1), 36-47. doi:10.1093/geront/gnp067

Housley, W. \& Fitzgerald, R. (2009). Membership categorization, culture and norms in action. Discourse E Society, 20(3), 345-362. doi:10.1177/0957926509102405

Jokinen, A., Juhila, K. \& Suoninen, E. (2012). Kategoriat, kulttuuri \& moraali. Johdatus kategoria-analyysiin. Tampere: Vastapaino.

Jolanki, O. (2004). Moral argumentation in talk about health and old age. Health, 8(4), 483-503. doi:10.1177/1363459304045700

Jolanki, O. (2009). Agency in talk about old age and health. Journal of Aging Studies, 23(4), 215-226. doi: 10.1016/j.aging.2007.12.020

Jones I. \& Higgs P. (2010). The natural, the normal and the normative: contested terrains in ageing and old age. Social Science Eo Medicine, (71)8, 15131519. doi: 10.1016/j.socscimed.2010.07.022

Jones, R. (2006). 'Older people' talking as if they are not older people: positioning theory as an explanation. Journal of Aging Studies, 20(1), 79-91. doi:10.1016/j.aging.2004.12.003

Juhila, K. (2012). Ongelmat, niiden selittäminen ja kategoriat. Teoksessa Jokinen, A., Juhila, K. \& Suoninen, E. (toim.) Kategoriat, kulttuuri $\mathcal{E}^{\circ}$ moraali. Johdatus kategoria-analyysiin (s. 131-172). Tampere: Vastapaino.

Juhila, K., Jokinen, A. \& Suoninen, E. (2012). Kategoria-analyysin teesit. Teoksessa Jokinen, A., Juhila, K. \& Suoninen, E. (toim.) Kategoriat, kulttuuri $E$ moraali. Johdatus kategoria-analyysiin (s. 45-88). Tampere: Vastapaino.

Lamb, S. (2014). Permanent personhood or meaningful decline? Towards a critical anthropology of successful aging. Journal of Aging Studies, (29), 41-52. doi:10.1016/j.aging.2013.12.006

Marttila A., Johansson E., Whitehead M. \& Burström B. (2013). Keep going in adversity - using a resilience perspective to understand the narratives of long-term social assistance recipients in Sweden. International Journal for Equity in Health, 12(8). doi:10.1186/1475-9276-12-8

Nakashima, M. \& Canda, E. (2005). Positive dying and resiliency in later life: a qualitative study. Journal of Aging Studies, 19(1), 109-125. doi:10.1016/j.aging.2004.02.002

Nicholson, C., Meyer, J., Flatley, M. \& Holman, C. (2013). The experience of living at home with frailty in old age: a psychosocial qualitative study. International Journal of Nursing Studies, 50(9), 1172-1179. doi:10.1016/j.ijnurstu.2012.01.006

Nikander, P. (2000). 'Old' vs. 'little girl”: a discursive approach to age categorization and morality. Journal of Aging Studies, 14(4), 335-358. doi: 10.1016/S0890-4065(00)80001-8

Nikander, P. (2002). Age in action: membership work and stage of life categories in talk. Academia Scientiarum Fennica, (321).

Nikander, P. (2009). Doing change and continuity: 
age identity and the micro-macro divide. Ageing E Society, 29(6), 863-881. doi:10.1017/S0144686X09008873

Näslund, S. (2017). Age ascription as a resource and a source of resistance - an interactional study of health professionals' castings of patients into the category 'old'. Journal of Aging Studies, 41, 28-35. doi:10.1016/j.jaging.2017.03.001

Paoletti, I. \& Gomes, S. (2014). Future talk in later life. Journal of Aging Studies, 29, 131-141. doi: 10.1016.2014.01.005

Pirhonen, J., Ojala, H., Lumme-Sandt, K. \& Pietilä, I. (2016). 'Old but not that old': Finnish community-dwelling people aged 90+ negotiating their autonomy. Ageing E Society, 36(8), 1625-1644. doi:10.1017/S0144686X15000525

Polson, E., Gillespie R. \& Myers D. (2018). Hope and resilience among vulnerable, community-dwelling older persons. Social Work and Christianity, 45(1) 60-81.

Puts, M., Shekary, N., Widdershoven, G., Heldens, J. \& Deeg, D. (2009). The meaning of frailty according to Dutch older frail and non-frail persons. Journal of Aging Studies, 23(4), 258-266. doi:10.1016/j.aging.2008.03.002

Rebagliati, G., Sciumè, L., Iannello, P., Mottini, A., Antonietti, A., Caserta, V., Gattoronchieri V., Panella, L. \& Callegari, C. (2016). Frailty and resilience in an older population. The role of resilience during rehabilitation after orthopedic surgery in geriatric patients with multiple comorbidities. Functional Neurology, 31(3), 171-177. doi: 10.11138/FNeur/2016.31.3.171

Rockwood, K., Song, X., MacKnight, C., Bergman, H., Hogan, D., McDowell, I. \& Mitnitski, A. (2005). A global clinical measure of fitness and frailty in elderly people. Canadian Medical Association Journal, 173(5), 489-495. doi:10.1503/cmaj.050051

Róin, Á. (2014). Embodied ageing and categorisation work amongst retirees in the Faroe Islands. Journal of Aging Studies, 31, 83-92. doi:10.10116/jaging.2014.09.001

Saarenheimo, M. (2014). Mitä vanhuudelle on tapahtunut. Haettu 28.8.2018 osoitteesta: https://issuu.com/eloisaika/docs/mit__vanhuudelle_on_tapahtunut
Saarenheimo, M. (2017). Vanhenemisen taito. Tampere: Vastapaino.

Sacks, H. (2006). 'The baby cried. The mommy picked it up.' Teoksessa Jaworski, A. \& Coupland N. (toim.) The Discourse Reader. Second Edition. (s. 239-245). London: Routledge.

São José J., Timonen V., Amado C. \& Santos S. (2017). A critique of the Active Ageing Index. Journal of Aging Studies. (40), 49-56. doi:10.1016/j.jaging.2017.01.001

Sapountzaki, K. \& Dandoulaki, M. (2006). Resilience to risks: the hidden defense against the limitations of planning. Haettu 12.9.2018 osoitteesta: https:// www.researchgate.net/publication/235799370_ Resilience_to_Risks_The_Hidden_Defense_ Against_the_Limitations_of_Planning

Skilbeck, J., Arthur, A. \& Seymour, J. (2018). Making sense of frailty: An ethnographic study of the experience of older people living with complex health problems. International Journal of Older People Nursing, 13(1), e12172. doi: 10.1111/opn.12172

Suoninen, E. (2012). Identiteettien rakentuminen. Teoksessa Jokinen, A., Juhila, K. \& Suoninen, E. (toim.) Kategoriat, kulttuuri $\mathcal{E}^{2}$ moraali. Johdatus kategoria-analyysiin (s. 89-129). Tampere: Vastapaino.

Wagnild, G. \& Young, H. (1993). Development and psychometric evaluation of the resilience scale. Journal of Nursing Measurement, (1)2, 165-178.

Warmoth, K., Lang, I., Phoenix, C., Abraham, C., Andrew, M., Hubbard, R. \& Tarrant, M. (2016). 'Thinking you're old and frail': a qualitative study of frailty in older adults. Ageing $\mathcal{E}^{2}$ Society, 36(7), 1483-1500. doi: 10.1017/S0144686X1500046X

Wild, K., Wiles, J. \& Allen, R. (2013). Resilience: thoughts on the value of the concept for critical gerontology. Ageing E Society, 33(1), 137-158. doi:10.1017/S0144686X11001073

Williamson, T. \& Paslawski, T. (2016). Resilience in dementia: perspectives of those living with dementia. Canadian Journal of Speech-Language Pathology and Audiology, 40(1), 1-15.

Zimmerman, H. \& Grebe, H. (2014). "Senior coolness": living well as an attitude in later life. Journal of Aging Studies, 28, 22-34. doi:10.1016/j.aging.2013.11.002 